\title{
PELAKSANAAN PRINSIP GOOD CORPORATE GOVERNANCE PADA BANK SYARIAH MELALUI PERAN DEWAN PENGAWAS SYARIAH
}

\author{
Taufan Adi Permana Madjid, Lastuti Abubakar \\ Program Magister Ilmu Hukum-Fakultas Hukum Universitas Padjadjaran \\ taufan18002@mail.unpad.ac.id \\ DOI: https://doi.org/10.29313/sh.v16i1.5132
}

\begin{abstract}
ABSTRAK
Salah satu isu hukum strategis dalam pengembangan perbankan syariah adalah kepatuhan terhadap prinsip tata kelola berbasis syariah, yang salah satunya adalah kewajiban memiliki Dewan Pengawas Syariah sebagai lembaga yang melakukan pengawasan internal untuk memastikan kepatuhan terhadap prinsip syariah. Tulisan ini bertujuan untuk mengetahui peran Dewan Pengawas Syariah dalam pertumbuhan bank syariah di Indonesia sesuai dengan pelaksanaan good corporate governance. Pelaksanaan Good Corporate Governance pada Bank Syariah di Indonesia tak luput dari kinerja Dewan Pengawas Syariah (DPS). Dewan Pengawas Syariah yang bertugas meneliti dan membuat rekomendasi produk baru dari bank yang diawasinya serta melakukan pengawasan terhadap bank syariah kegiatan usaha yang dilakukannya mematuhi prinsip syariah sebagaimana telah ditentukan oleh fatwa dan syariah Islam. Jelas bahwa peran Dewan Pengawas Syariah dengan memaksimalkan kemampuan yang dimiliki Dewan Pengawas Syariah merupakan salah satu yang fundamental. Dewan Pengawas Syariah diharapkan dapat lebih mengawasi dan memahami pola usaha perbankan syariah sehingga perbankan syariah dapat menjadi pilihan utama nasabah perbankan di Indonesia.
\end{abstract}

Kata Kunci: Good Corporate Governance, Dewan Pengawas Syariah, Bank Syariah.

\section{ABSTRACT}

One of the strategic legal issues in the development of Islamic banking is compliance with the principles of sharia-based governance, one of which is the obligation to have a Sharia Supervisory Board as an institution that carries out internal supervision to ensure compliance with sharia principles. This paper aims to determine the role of 
the Sharia Supervisory Board in the growth of Islamic banks in Indonesia in accordance with the implementation of good corporate governance. The implementation of Good Corporate Governance in Islamic Banks in Indonesia does not escape the performance of the Sharia Supervisory Board (DPS). The Sharia Supervisory Board which is in charge of researching and making recommendations on new products from the banks it supervises and supervising Islamic banks the business activities they carry out comply with sharia principles as determined by fatwas and Islamic sharia. It is clear that the role of the Sharia Supervisory Board by maximizing the capabilities of the Sharia Supervisory Board is a fundamental one. The Sharia Supervisory Board is expected to be able to better monitor and understand the pattern of Islamic banking business so that Islamic banking can become the main choice of banking customers in Indonesia..

Keywords: Good Corporate Governance, The Sharia Supervisory Board, Sharia Banking

\section{A. PENDAHULUAN}

\section{Latar Belakang Masalah}

Perkembangan kegiatan perbankan saat ini tidak hanya didominasi oleh bank- bank konvensional yang sudah lebih dulu ada dan eksis di Indonesia, bank dalam sektor syariah pun saat ini sudah mulai berkembang dan mulai diterima di masyarakat ${ }^{1}$ Perbankan Syariah seperti halnya perbankan pada umumnya merupakan lembaga intermediasi keuangan (financial intermediary institution) yakni lembaga yang melakukan kegiatan menghimpun dana dari masyarakat serta mendistribusikan dana tersebut dalam bentuk kredit atau pembiayaan. Dengan munculnya Undang-Undang No 21 Tahun 2008 tentang Perbankan Syariah (selanjutnya disebut UU Perbankan Syariah) pada Pasal 19 dijelaskan bahwa

\footnotetext{
${ }^{1}$ Aldira Maradita. Karakteristik Good Corporate Governance pada Bank Syariah dan Konvensional. Yuridika. Vol. 29 No. 2. Mei-Agustus 2014, hlm. 192.
} 
perbankan syariah dapat menghimpun dana simpanan serta investasi dan menyalurkan pembiayaan tak luput pula beberapa kegiatan perbankan konvensional yang berasaskan syariah walaupun memang perbankan syariah memiliki produk sosial dalam hal ini seperti menghimpun dan menyalurkan zakat dan wakaf pada perbankan syariah.

Pada akhir tahun 2016, perbankan syariah Indonesia yang terdiri dari Bank Umum Syariah (BUS), Unit Usaha Syariah (UUS) dan Bank Pembiayaan Rakyat Syariah (BPRS) mencatatkan pertumbuhan aset, pembiayaan yang diberikan (PYD) dan dana pihak ketiga (DPK) industri perbankan syariah nasional tahun 2016 tumbuh signifikan, masing-masing sebesar 20,28\%, 16,41\% dan 20,84\%. Total aset, PYD, dan DPK industri perbankan syariah nasional pada tahun 2016 masing-masing mencapai Rp365,6 triliun, Rp254,7 triliun dan Rp285,2 triliun. ${ }^{2}$ Seiring pula dengan perkembangan industri perbankan syariah yang ditandai dengan semakin beragamnya produk perbankan syariah dan bertambahnya jaringan pelayanan perbankan syariah, maka Good Corporate Governance pada industri perbankan syariah menjadi semakin penting untuk dilaksanakan. ${ }^{3}$

Pelaksanaan GCG pada industri perbankan syariah harus berlandaskan pada lima prinsip dasar yang mana dijelaskan pada Undang-Undang Perbankan Syariah pada pasal 34 serta pula pelaksanaan GCG pada perbankan syariah pula diwajibkan pada Peraturan Bank Indonesia Nomor 11/33/PBI/2009 tentang Pelaksanaan Good Corporate Governance bagi Bank Umum Syariah dan Unit Usaha Syariah (selanjutnya disebut PBI GCG Perbankan Syariah). Pertama, transparansi (transparency), yaitu keterbukaan dalam mengemukakan informasi yang material dan relevan serta keterbukaan dalam proses pengambilan keputusan. Kedua, akuntabilitas (accountability) yaitu kejelasan fungsi dan pelaksanaan pertanggungjawaban organ bank sehingga pengelolaannya berjalan secara efektif. Ketiga, pertanggungjawaban (responsibility) yaitu kesesuaian pengelolaan bank

\footnotetext{
${ }^{2}$ Lihat OJK, Roadmap Pengembangan Keuangan Syariah Indonesia 2017-2019, Juni 2017, hal 9.

3 Biki Zulfikri Rahmat. "Optimalisasi DPS Dalam Pelaksanaan GCG di BPRS Harum Hikmahnugraha”. Amwaluna. Vol. 1 No. 2. Juli 2017. hlm. 280.
} 
dengan peraturan perundang-undangan yang berlaku dan prinsip- prinsip pengelolaan bank yang sehat. Keempat, profesional (professional) yaitu memiliki kompetensi, mampu bertindak obyektif dan bebas dari pengaruh/tekanan dari pihak manapun (independen) serta memiliki komitmen yang tinggi untuk mengembangkan bank syariah. Kelima, kewajaran (fairness) yaitu keadilan dan kesetaraan dalam memenuhi hak-hak stakeholders berdasarkan perjanjian dan peraturan perundang-undangan yang berlaku. ${ }^{4}$

Dalam rangka menerapkan kelima prinsip dasar tersebut, bank wajib berpedoman pada berbagai ketentuan dan persyaratan yang terkait dengan pelaksanaan GCG. Selain itu dalam pelaksanaan GCG, industri perbankan syariah juga harus memenuhi prinsip syariah (sharia compliance). Ketidaksesuaian tata kelola bank dengan prinsip syariah akan berpotensi menimbulkan berbagai risiko terutama risiko reputasi bagi industri perbankan syariah. Pelaksanaan GCG perbankan syariah tidak hanya dimaksudkan untuk memperoleh pengelolaan bank yang sesuai dengan lima prinsip dasar dan sesuai dengan prinsip syariah, akan tetapi juga ditujukan untuk kepentingan yang lebih luas. Kepentingan ini antara lain adalah untuk melindungi kepentingan stakeholders dan meningkatkan kepatuhan terhadap peraturan perundang- undangan yang berlaku serta nilai etika yang berlaku secara umum pada industri perbankan syariah. ${ }^{5}$

Keharusan tampilnya bank syariah sebagai pionir penegakan GCG dibanding bank konvensional, karena permasalahan governance dalam bank syariah ternyata berbeda dengan bank konvensional. Pertama, bank syariah memiliki kewajiban untuk mematuhi prinsip-prinsip syariah (shari'ah compliance) dalam menjalankan bisnisnya. ${ }^{6}$ Oleh karena itu, Dewan Pengawas Syariah memainkan peran yang penting dalam governance structure perbankan syariah. Kedua, karena potensi terjadinya information asymmetry tinggi bagi perbankan syariah maka permasalahan agency theory menjadi sangat relevan. Hal ini terkait dengan

\footnotetext{
${ }^{4}$ Ibid, hlm. 280

${ }^{5}$ Ibid, hlm. 280.

${ }^{6}$ Algaoud dan Lewis. "Perbankan Syariah; Prinsip, Praktik, dan Prospek". PT. Serambi Ilmu Semesta, Jakarta, 2004, hlm. 26
} 
permasalahan tingkat akuntabilitas dan transparansi penggunaan dana nasabah dan pemegang saham. Berdasarkan uraian di atas, permasalahan keterwakilan investment account holders dalam mekanisme GCG menjadi masalah strategis yang mesti mendapat perhatian dari bank syariah. Ketiga, dari perspektif budaya korporasi, perbankan syariah semestinya melakukan transformasi budaya dimana nilai-nilai etika bisnis Islami menjadi karakter yang inheren dalam praktik bisnis perbankan syariah. $^{7}$

Kondisi di atas menuntut bank syariah memberikan jaminan mengenai kesesuaian syariah untuk seluruh aktivitasnya ataupun prinsip-prinsip prudensial yang dibutuhkan dari sebuah bank, disamping pelayanan bagi konsumen. Berdasarkan PBI GCG Perbankan Syariah menjelaskan pelaksanaan GCG harus diwujudkan dalam tugas dan tanggung jawab DPS. Apabila kinerja DPS berjalan dengan baik diharapkan pelaksanaan GCG atau tata kelola bank syariah tersebut baik dan konsisten. Namun, peran pengawasan yang dilakukan DPS saat ini masih belum optimal.

Dewan Pengawas Syariah menjadi salah satu hal wajib pada perbankan syariah seperti tertuang pada Pasal 32 UU Perbankan Syariah. Persyaratan menjadi DPS memang belum ada payung hukumnya tetapi DSN-MUI Institute sering melakukan beberapa pelatihan calon DPS, di situ dijelaskan beberapa kriteria untuk mengikuti pelatihan tersebut seperti: ${ }^{8}$

1. Merupakan calon Dewan Pengawas Syariah (DPS) di Lembaga Keuangan Syariah dengan menyerahkan surat keterangan DPS/rekomendasi dari Lembaga Keuangan, Bisnis, atau Ekonomi Syariah;

2. Memiliki salah satu persyaratan strata pendidikan minimal sebagai berikut:

7. Pramono Sigit,. "Corporate Governance in Islamic Banking: Critical Issues and The Suitability of Conventional Corporate Governance Mechanism". Jurnal Islamic Economics And Finance Journal, Vol. 1 No. 1, Juli 2008., hlm. 32.

8 https://dsnmuiinstitute.com/pelatihan/pelatihan-dasar-calon-dps-lembaga-keuangan-syariah-lks10-12- januari-2019-jakarta/ (diakses pada 12 Desember 2018, pukul 09.30 WIB) 
a. S1 bidang ilmu kesyari'ahan, S1 bidang lain dengan pengalaman bidang kesyariahaan minimal 3 tahun,

b. SMA/MA/sederajat dengan wawasan keilmuan syariah yang memadai berdasarkan rekomendasi MUI. Menyerahkan dokumen softcopy (hasil pindai) berupa a. pasfoto skala 3 x 4, b. KTP, dan c. ijazah terakhir; serta

3. Membayar biaya pelatihan sesuai dengan ketentuan."

Dilihat dari kriteria tersebut bahwa untuk menjadi DPS memang mengutamakan pada sosok yang sudah memahami bidang kesyari'ahan. Akan tetapi alangkah baiknya bahwa untuk dapat menjadi DPS tidak hanya mampu menguasai bidang kesyari'ahan tetapi paham mengenai berbagai hal lain seperti manajemen perbankan, peraturan- peraturan yang berlaku bagi perbankan syariah pula agar peran DPS ke depannya bisa lebih luas dan mencakup segala kebutuhan perbankan syariah untuk dapat terus tumbuh pada perkembangan perbankan di Indonesia.

\section{Identifikasi Masalah}

Artikel ini akan membahas bagaimana peran Dewan Pengawas Syariah pada bank syariah di Indonesia sesuai dengan pelaksanaan good corporate governance.

\section{Metode Penelitian}

Penelitian ini bersifat deskriptif analitis yaitu menggambarkan dan menganalisis data yang diperoleh berdasarkan data sekunder. Metode pendekatan yang digunakan adalah yuridis normatif, yang lebih menitikberatkan pada studi kepustakaan, yang selanjutnya dianalisis secara yuridis kualitatif.

\section{B. PEMBAHASAN}

\section{a. Tata Kelola yang Baik (Good Governance) pada Perbankan Syariah}

Tata kelola yang baik bagi perbankan syariah tentu berbeda dengan tata kelola bank konvensional, karena tujuan akhir dari aktivitas bank syariah tidak dapat dilepaskan dari maqasid syariah, yaitu tujuan utama yang ingin diwujudkan oleh syariah, yaitu "obligation of the shariah is to provide the well being of all 
humankind. Which lies in safeguarding their faith, their human self (nafs), their intellect (aql), their progeny (nasl) and their wealth (mal)" "9 Penerapan tata kelola yang baik, konsisten dan berkelanjutan selain bertujuan untuk melindungi kepentingan stakeholders, juga meningkatkan kepatuhan terhadap prinsip syariah. Kepatuhan terhadap prinsip syariah ini yang akan menjadi pembeda antara lingkup, urgensi, dan penerapan tata kelola di perbankan syariah.

Prinsip syariah ini selanjutnya akan terlihat dari prinsip dasar operasional perbankan syariah dimana modal bank dan simpanan disalurkan melalui transaksi pembiayaan berbasis bagi hasil, komisi dan marjin. Selain itu, bank syariah memiliki fungsi sosial sebagai penampung dana zakat dan juga pemberi pinjaman kebajikan/ dana talangan (qard dan qardulhasan) yang tidak dikenal dalam perbankan konvensional seperti yang tertuang Pasal 4 UU Perbankan. Dari sisi tujuan, prinsip syariah mencirikan karakteristik yang lebih mengedepankan kesejahteraan umat dan terciptanya pertumbuhan berkelanjutan dengan fokus pada sektor riil yang menciptakan nilai tambah. Itu sebabnya sistem governance pada perbankan syariah dianggap lebih kompleks daripada perbankan konvensional karena selain harus memperhatikan regulasi secara umum, juga harus mematuhi prinsip syariah yang berasal dari hukum Islam untuk dapat berkompetisi dalam pasar. ${ }^{10}$ Sebagai bagian dari sistem perbankan syariah, tata kelola perbankan syariah di Indonesia akan sangat dipengaruhi oleh sistem hukum Indonesia yang lebih dipengaruhi oleh sistem civil law, dimana peraturan perundang-undangan menjadi sumber utama, sehingga prinsip syariah yang tertuang dalam Fatwa DSN harus terlebih dahulu diterjemahkan ke dalam hukum positif, khususnya peraturan yang dikeluarkan oleh otoritas jasa keuangan baik OJK maupun Bank Indonesia. Kerja sama ke dua otoritas ini diperlukan untuk menghindari duplikasi dan saling melengkapi pengaturan perbankan syariah khususnya. ${ }^{11}$

\footnotetext{
${ }^{9}$ Mehmet Asutay dalam Taufan. “An Introduction to Islamic Moral Economy”. (Durham Islamic Finance Summer School, 201, hlm. 28.

${ }^{10}$ Frederick V. Perry. "The Corporate Governance of Islamic Banks: A Better Way of Doing Business?'.Michigan State Journal of International Law. Vol.19:2, 2011, hlm. 266.

${ }^{11}$ Lihat OJK, Booklet Perbankan Indonesia 2016, Edisi 3, Maret 2016, hlm. 5.
} 


\section{b. Implementasi Shariah Governance Sebagai Upaya Meningkatkan Pertumbuhan Perbankan Syariah}

Pertumbuhan perbankan syariah tidak dapat dilepaskan dari keberhasilannya menjalankan fungsinya sebagai agent of services, agent of trust, serta agent of development. Menjaga dan meningkatkan kepercayaan masyarakat terhadap produk dan layanan perbankan yang patuh terhadap prinsip syariah merupakan salah satu cara untuk mempercepat pertumbuhan perbankan syariah. Isu strategis berupa mispersepsi dan rendahnya tingkat kepercayaan masyarakat terhadap perbankan syariah dapat diubah melalui implementasi kebijakan perbaikan kuantitas dan kualitas sumber daya manusia. Sumber daya manusia yang kompeten merupakan implementasi prinsip akuntabilitas, yang mengandung unsur kejelasan fungsi dalam organisasi dan cara mempertanggungjawabkannya. Pelaku perbankan syariah harus dapat mempertanggungjawabkan kinerjanya secara transparan dan wajar. Untuk itu bisnis syariah harus dikelola secara benar, terukur dan sesuai dengan kepentingan para stakeholder. Selain itu, akuntabilitas merupakan prasyarat yang diperlukan untuk mencapai bisnis yang berkesinambungan. Berdasarkan pemikiran tersebut, maka diperlukan hal sebagai berikut: ${ }^{12}$

Perbankan syariah harus memiliki sumber daya manusia yang menguasai prinsip syariah untuk memastikan bahwa aktivitas, produk, dan layanan perbankan patuh terhadap prinsip syariah; Menetapkan kewajiban dan tanggung jawab setiap sumber daya manusia secara jelas. Selanjutnya, untuk mengimbangi profesionalisme sumber daya manusia, baik otoritas maupun perbankan syariah wajib melakukan edukasi melalui peningkatan literasi dan preferensi masyarakat, serta penyediaan informasi yang jelas, sehingga terdapat pengetahuan yang seimbang dan selaras antara bank syariah sebagai institusi dan masyarakat. Kegiatan ini sejalan dengan makna yang terkandung dalam prinsip transparansi, yaitu adanya unsur pengungkapan dan penyediaan informasi yang mudah diakses oleh seluruh pemangku kepentingan. Transparansi sangat diperlukan bagi perbankan syariah agar dapat menjalankan kegiatannya secara objektif dan sehat.

${ }^{12}$ Lihat OJK, Booklet Perbankan Indonesia 2016, Edisi 3, Maret 2016, hlm. 5. 
Transparansi disini berarti perbankan syariah mempunyai kewajiban ${ }^{13}$ (a) Menyediakan informasi tepat waktu, memadai, jelas, akurat serta mudah diakses oleh semua pemangku kepentingan sesuai dengan haknya. (b) Tidak mengurangi kewajiban bank syariah untuk memenuhi kewajiban kerahasiaan bank, rahasia jabatan dan perlindungan hak pribadi. (c) Menyediakan pedoman prilaku yang telah disepakati; (d) Meyakini bahwa semua prosedur, akad, produk dan layanan telah sesuai dengan prinsip syariah yaitu halal, tayib, ikhsan dan tawazun.

Selanjutnya, selain mengubah persepsi dan meningkatkan kepercayaan masyarakat, untuk menjaga pertumbuhan, perbankan syariah wajib menerapkan prinsip responsibilitas untuk menjaga keberlanjutan usaha dan mendapat pengakuan sebagai pelaku bisnis yang baik. Oleh karena itu, bank syariah perlu melakukan hal berikut: ${ }^{14}$ (a) Berpegang pada prinsip kehati-hatian dan memastikan kepatuhan terhadap prinsip syariah dan peraturan perundang-undangan, serta peraturan internal bank.(b) Melaksanakan akad yang telah dibuat; (c) Melaksanakan tanggung jawab sosial, khususnya terhadap lingkungan dan masyarakat setempat melalui zakat, infaq dan sadaqah.

Selanjutnya, melalui penerapan prinsip independensi, perbankan syariah diharapkan dapat istiqamah, berpegang teguh pada kebenaran dan tidak dapat di intervensi oleh pihak manapun, sehingga dapat memberikan jaminan bagi masyarakat bahwa dalam melakukan kegiatannya, senantiasa memperhatikan kepentingan seluruh stakeholder, melalui implementasi good corporate governance, mispersepsi dapat diubah, kepercayaan masyarakat dapat ditingkatkan, dan tujuan prinsip syariah untuk menciptakan kesejahteraan dan bisnis yang berkelanjutan dapat dicapai. Terakhir, implementasi prinsip kewajaran dan kesetaraan mengandung unsur kesamaan perlakuan, dan manifestasi adil dalam dunia bisnis. Dalam melaksanakan kegiatannya, perbankan syariah harus memperhatikan kepentingan pemangku kepentingan. ${ }^{15}$

\footnotetext{
${ }^{13}$ Ibid.

${ }^{14}$ Ibid.

${ }^{15} \mathrm{Ibid}, \mathrm{hlm} .130$.
} 
Salah satu yang membedakan perbankan syariah dengan perbankan konvensional adalah kewajiban Bank syariah dan Bank konvensional yang memiliki Unit Usaha Syariah untuk membentuk Dewan Pengawas Syariah (DPS), yang diangkat oleh Rapat Umum Pemegang Saham (RUPS) atas rekomendasi Majelis Ulama Indonesia (MUI). ${ }^{16}$ Dewan Pengawas Syariah (DPS) ini bertugas memberikan nasihat dan saran kepada direksi serta mengawasi kegiatan Bank agar sesuai dengan prinsip syariah yaitu prinsip hukum Islam di bidang perbankan syariah yang tertuang dalam bentuk fatwa Dewan Syariah Nasional MUI, termasuk memastikan implementasi tata kelola berbasis syariah. Tugas dan tanggung jawab DPS meliputi ${ }^{17}$ : (a) Menilai dan memastikan pemenuhan prinsip syariah atas pedoman operasional dan produk yang dikeluarkan bank (b) Mengawasi proses pengembangan produk baru bank agar sesuai dengan fatwa DSN-MUI; (c) Meminta fatwa kepada DSN-MUI (d) Melakukan review secara berkala atas pemenuhan prinsip syariah terhadap mekanisme penghimpunan dana dan penyaluran dana serta pelayanan jasa Bank; (e) Meminta data dan informasi terkait dengan aspek syariah dari satuan kerja Bank.

Apabila melihat tugas dan tanggung jawab DPS di atas, maka dapat disimpulkan bahwa tugas utama DPS hanya memastikan pemenuhan prinsip syariah, baik proses, produk dan layanan, bukan pada pertumbuhan dan pemasaran bank syariah. Mengacu pada kedudukan DPS dalam struktur perbankan syariah, diperlukan jaminan bahwa pengawasan yang dilakukan sesuai dengan tujuan prinsip syariah. Potensi benturan kepentingan dapat terjadi mengingat DPS merupakan bagian dari struktur organisasi bank syariah, yang diangkat oleh RUPS, sementara tugasnya melakukan pengawasan terhadap pengurusan yang dilakukan oleh Direksi. Independensi DPS diperlukan untuk memastikan kepatuhan terhadap prinsip syariah bagi kepentingan seluruh stakeholder dan meningkatkan kepercayaan masyarakat terhadap perbankan syariah. Salah satu cara untuk

\footnotetext{
${ }^{16}$ Lihat Pasal 32 UU No: 21 Tahun 2008 Tentang Perbankan Syariah.

${ }^{17}$ Lihat PBI No: 11/33/PBI/2009 Tentang Pelaksanaan Tatakelola Perusahaan yang Baik oleh Bank Umum Syariah dan Unit Usaha Syariah
} 
menghindari benturan kepentingan tersebut adalah memperkuat independensi DPS. Dalam praktik di beberapa negara, struktur DPS akan berkoordinasi langsung dengan unit atau departemen pengembangan produk dan departemen kepatuhan terhadap syariah, untuk memastikan bahwa seluruh fungsi-fungsi bank mematuhi prinsip syariah. Selain struktur DPS, independensi DPS dapat diwujudkan melalui kompetensi anggota DPS, yang dapat dipenuhi melalui kewajiban berikut:

1. Anggota DPS wajib melalui proses sertifikasi yang dikeluarkan oleh lembaga yang ditunjuk. Saat ini tidak ada kualifikasi standar, sertifikasi atau standar akreditasi untuk anggota DPS yang dapat menjamin kualitas dan menjaga perkembangan, termasuk perbankan syariah. $^{18}$

2. Anggota dewan pengawas tidak saja menguasai prinsip syariah, melainkan juga menguasai perbankan, dan bidang-bidang lain yang diperlukan untuk pengembangan produk dan layanan perbankan syariah.

3. Proses rekrutmen anggota DPS wajib bersifat terbuka, dan memenuhi persyaratan yang ditetapkan, termasuk kalangan akademisi yang bersertifikasi.

Ketiga hal di atas diperlukan untuk mengatasi konsep umum yang keliru bahwa Anggota DPS hanya diwakili oleh ahli syariah saja. Pendekatan yang tepat adalah memasukkan beragam ahli seperti akuntan, manajemen bisnis dan ahli hukum. Saat ini, penetapan anggota DPS mengacu pada PBI No: 14/6/PBI/2012 yang menetapkan uji dasar kelayakan dan kepatutan untuk anggota DPS bank dan Unit Usaha Syariah. Namun demikian, PBI tersebut masih bersifat umum dan tidak secara spesifik menyediakan prosedur yang kokoh untuk penunjukan anggota DPS. Satu hal yang perlu diperhatikan dalam menetapkan standar adalah, pedoman yang digunakan IFSB dan AAOIFI bahwa audit syariah merupakan bagian penting dalam kerangka tata kelola

${ }^{18}$ Masterplan Arsitektur Keuangan Syariah Indonesia, Badan APPENAS, Juli 2016, hlm. 145. 
syariah untuk lembaga keuangan yang menawarkan produk dan layanan berbasis syariah. $^{19}$

Selanjutnya, keberhasilan implementasi tata kelola syariah tidak dapat dilepaskan dari peran pemerintah, kesiapan regulasi, pelaku usaha dan masyarakat. Oleh karena itu keberhasilan implementasi tatakelola pada bank syariah akan sangat ditentukan oleh optimalisasi ke 4 pilar ini. ${ }^{20}$

1. Political will pemerintah, untuk mendukung dan memfasilitasi industri keuangan syariah menjadi pendorong bagi percepatan pertumbuhan perbankan syariah di Indonesia, mengingat karakteristik pertumbuhan perbankan syariah bersifat bottom up, dibangun dari bawah, sehingga perkembangannya sejalan dengan kebutuhan dan kesadaran masyarakat. Faktanya, pertumbuhan perbankan syariah Indonesia semakin baik seiring dengan perhatian dan keinginan pemerintah untuk memfasilitasi dan mengatur secara baik, termasuk menyediakan kelembagaan yang akan mendukung tumbuh kembang industri perbankan syariah, serta melakukan pengawasan dan penegakan hukum untuk menciptakan industri perbankan yang sehat dan kokoh. Political will pemerintah semakin menguat dengan dibentuknya Komite Nasional Pengembangan Keuangan Syariah Indonesia, koordinasi antara pemerintah dan otoritas jasa keuangan. Selain itu, otoritas jasa keuangan mendorong peningkatan kesadaran masyarakat terhadap industri keuangan syariah melalui program literasi keuangan dan edukasi masyarakat secara intensif dan berkelanjutan.

2. Regulasi yang kokoh dan penyelesaian sengketa yang tepat, sebagai dasar pelaksanaan aktivitas perbankan syariah yang dapat menjamin kepastian dan perlindungan hukum baik bagi pelaku usaha dan masyarakat. Saat ini perbankan syariah merupakan industri keuangan yang paling siap dari sisi regulasi, dengan diterbitkannya UU No: 21 Tahun 2008 Tentang Perbankan

${ }^{19}$ Lastuti Abubakar dan Tri Handayani. "Percepatan Pertumbuhan Perbankan Syariah Melalui Implementasi Tata Kelola Syariah". Law and Justice. Vol. 2 No. 2. Oktober 2017. hal. 131-132.

${ }^{20}$ Ibid. 
Syariah. Disamping itu, peraturan yang dikeluarkan oleh OJK dan Bank Indonesia yang dibentuk berdasarkan Fatwa DSN-MUI senantiasa mengikuti perkembangan industri perbankan syariah, khususnya mengenai pengembangan produk dan akad yang ditawarkan oleh perbankan syariah. Otoritas jasa keuangan telah menyiapkan lembaga yang akan memberikan jaminan dan perlindungan hukum bagi masyarakat dengan menerbitkan 2 POJK, yaitu POJK No: 1/POJK.07/2013 Tentang Perlindungan Konsumen Sektor Jasa Keuangan, yang menganut prinsip transparansi, perlakuan yang adil , keandalan, kerahasiaan dan keamanan data/ informasi konsumen dan penanganan pengaduan serta penyelesaian sengketa konsumen secara sederhana, cepat, dan biaya terjangkau, dan POJK No. 1/POJK.07/2014 Tentang Lembaga Alternatif Penyelesaian Sengketa Sektor Jasa Keuangan, yang bertujuan untuk memfasilitasi penyelesaian sengketa yang cepat, murah, adil, dan efisien. Ke dua POJK tersebut diharapkan dapat menjaga keberlangsungan industri keuangan syariah, dan mendorong naiknya tingkat kepercayaan masyarakat terhadap sektor jasa keuangan syariah, dengan sifat penyelesaian sengketa yang bertumpu pada win-win solution dan kehendak sukarela para pihak.

3. Kesiapan industri perbankan syariah dalam penyediaan produk dan layanan yang patuh pada prinsip syariah, berdasarkan data, hingga tahun 2016, jumlah pelaku perbankan syariah terdiri dari 13 Bank Umum Syariah (BUS), 21 Unit Usaha Syariah (UUS) dan 163 Bank Pembiayaan Rakyat Syariah (BPRS) dengan 2.163 jaringan kantor BUS dan UUS, sementara market share perbankan syariah baru mencapai 4,81\%. Kondisi ini tentu masih jauh dari target optimis yang sudah dicanangkan sejak diluncurkannya UU Perbankan Syariah. Bahkan berdasarkan data yang dikeluarkan OJK, perbankan syariah mengalami perlambatan pertumbuhan sejak tahun 2014, dari market share 4,85 $\%$ menjadi 4,83 \% di tahun 2015. Sementara itu, tingkat global, Indonesia memperoleh pengakuan internasional sebagai pendorong keuangan syariah di masa depan. Oleh karena itu, diperlukan upaya-upaya untuk mendorong 
percepatan pertumbuhan perbankan syariah guna memanfaatkan peluang global. Pemerintah sudah mempersiapkan infrastruktur hukum dengan menerbitkan roadmap perbankan syariah nasional 205-2019 yang berisi rencana pengembangan sektor perbankan syariah yang mengacu pada Masterpan Sektor Jasa Keuangan Indonesia, dan secara khusus telah menerbitkan Masterplan Arsitektur Keuangan Syariah Indonesia, yang dapat menjadi referensi bagi stakeholder perbankan syariah dalam pengembangan industri perbankan syariah.

\section{PENUTUP}

Pelaksanaan Good Corporate Governance pada Bank Syariah di Indonesia tak luput dari kinerja Dewan Pengawas Syariah (DPS). Dewan Pengawas Syariah yang bertugas meneliti dan membuat rekomendasi produk baru dari bank yang diawasinya serta melakukan pengawasan terhadap bank syariah kegiatan usaha yang dilakukannya mematuhi prinsip syariah sebagaimana telah ditentukan oleh fatwa dan syariah Islam. Jelas bahwa peran Dewan Pengawas Syariah dengan memaksimalkan kemampuan yang dimiliki Dewan Pengawas Syariah merupakan salah satu yang fundamental. Dewan Pengawas Syariah diharapkan dapat lebih mengawasi dan memahami pola usaha perbankan syariah sehingga perbankan syariah dapat menjadi pilihan utama nasabah perbankan di Indonesia.

Dewan Pengawas Syariah tidak hanya perlu memahami mengenai fatwa atau syariah Islam yang berlaku di Indonesia tetapi mampu memahami perbankan sehingga Dewan Pengawas Syariah tidak hanya mengawasi dari segi syariah compliance tetapi dapat menjadi pengawas pada segi perbankannya. 


\section{DAFTAR ISI}

\section{A. Buku}

Mehmet Asutay, An Introduction to Islamic Moral Economy, Durham Islamic Finance Summer School 2013, Durham, UK, 2013

Mervin K., Lewis., Latifa M., Al Haod, Perbankan Syariah, Prinsip Praktik Dan Prospek, Serambi Ilmu Semesta, Jakarta, 2005.

Pramono Sigit, Corporate Governance In Islamic Banking, Jakarta, 2008. Otoritas Jasa Keuangan, Booklet Perbankan Indonesia 2016, Edisi 3, Maret 2016.

\section{B. Jurnal}

Aldira Maradita, Karakteristik Good Corporate Governance pada Bank Syariah dan Konvensional, Yuridika, Vol. 29 No. 2, Mei-Agustus 2014.

Masterplan Arsitektur Keuangan Syariah Indonesia, BAPPENAS, Jakarta, 2016.

Biki Zulfikri Rahmat, Optimalisasi DPS Dalam Pelaksanaan GCG di BPRS Harum Hikmahnugraha, Amwaluna. Vol. 1 No. 2, Juli 2017.

Frederick V. Perry, The Corporate Governance of Islamic Bank: A Better Way of Doing Business? Michigan State Journal of International Law, Vol. 19: 2, 2011.

Issues And The Suitability of Conventional Corporate Governance Mechanism. Jurnal Islamic Economics And Finance Journal, Vol. 1 No. 1, Juli 2008.

Lastuti Abubakar dan Tri Handayani, Percepatan Pertumbuhan Perbankan Syariah Melalui Implementasi Tata Kelola Syariah, Law and Justice, Vol. 2 No. 2, Oktober 2017.

\section{Peraturan Perundang-Undangan}

Undang-Undang No 21 Tahun 2008 Tentang Perbankan Syariah

Peraturan Bank Indonesia No. 11/33/PBI/2009 Tentang Pelaksanaan Tatakelola Perusahaan Yang Baik oleh Bank Umum Syariah dan Unit Usaha Syariah 